\title{
A OFICINA DE CAMÕES (APONTAMENTOS SOBRE OS LUSÍADAS)
}

\section{CAMÕES IN THE WORKSHOP (NOTES ON THE LUSIADS)}

\author{
José Augusto Cardoso Bernardes \\ CLP - Universidade de Coimbra \\ https: / / orcid.org/0000-0002-8019-2465
}

\section{RESUMO}

Depois de um período em que o ensino dos autores canónicos não necessitava de justificação, encontramo-nos hoje numa fase em que as dúvidas ultrapassam as certezas. O que ensinar? Como ensinar? O que deve ser sujeito a avaliação? Apelando à sua experiência de mais de 30 anos na lecionação da cadeira de Estudos Camonianos, o autor propõe um guia de estudo sobre Os Lusíadas ponderando escolhas em função das novas circunstâncias e dos públicos reais que hoje frequentam a cadeira.

Palavras-Chave: Humanidades, Ensino da literatura, Camões, Bibliografia, Método de Estudo.

\begin{abstract}
After a period in which the teaching of canonical authors needed no justification, we are now at a time when there are more doubts than certainties. What should we teach? How should we teach? What should be evaluated? Drawing on his thirty-year experience in teaching the Camonian Studies Course, the author offers guidelines for the study of Os Lusiadas, weighing choices in light of the new circumstances and the actual students currently taking this course.
\end{abstract}

Keywords: Humanities, Teaching of Literature, Camões, Bibliography, Study Method 


\section{INTRODUÇÃO}

O que deve ensinar-se hoje sobre Os Lusíadas numa Faculdade de Letras? O que tem ainda para nos dizer um texto fundado em valores éticos e estéticos tão afastados do nosso tempo? Como levar jovens universitários a interessarem-se verdadeiramente por um autor que há 500 anos foi poeta e soldado? Estas perguntas acodem ao meu espírito sempre que, em cada semestre, inicio a lecionação da cadeira de Estudos Camonianos. São perguntas de base, que dão depois origem a muitas outras, relacionadas com métodos de ensino, apoio bibliográfico e critérios de avaliação.

Há 35 anos atrás, quando comecei a colaborar na lecionação da cadeira, o problema não se colocava da mesma forma. Os públicos eram homogéneos e essa circunstância constituía uma referência de conforto para quem ensinava. Sabia-se que, em geral, os estudantes acabariam por ser um dia professores de Português e, no desempenho dessa função, precisariam, por sua vez, de ensinar Camões. Objetivos, conteúdos e patamares de exigência encontravam-se assim implicitamente definidos em função de necessidades instrumentais. Havia acertos a fazer em cada ano mas eram de natureza pontual. E neles prevalecia a autoridade do Professor. Justificava-se que assim fosse: só ele possuía uma longa e intensa familiaridade com os textos poéticos; e só ele detinha a vasta erudição que assentava na leitura dos comentaristas que, desde o século XVI se vinham empenhando em esclarecer e aprofundar os sentidos da mensagem camoniana. Com base nessa autoridade natural, foi estabelecido um pequeno conjunto de princípios, que viria a nortear o funcionamento da cadeira de forma relativamente estável ${ }^{1}$ :

1 Tendo sido formalmente fundada na Faculdade de Letras de Lisboa em 1925 e tendo aí sido regida (ainda que de forma descontinuada) por nomes destacados do camonismo português como José Maria Rodrigues, Hernâni Cidade e mais recentemente, Maria Vitalina Leal de 
a - O ensino de Camões (e, em geral, o ensino de autores anteriores ao século XIX) não pode prescindir do conhecimento proporcionado pela investigação filológica. Isto quer dizer, em concreto, que na Universidade não se pode ensinar Camões sem ter lido os nomes maiores do camonismo, desde Manuel de Faria e Sousa até Maria Vitalina Leal de Matos e Vítor Aguiar e Silva, para citar dois nomes que na altura (na década de oitenta do século passado) se situavam no quadrante mais avançado dos estudos camonianos;

b - Do mesmo modo, nada deve substituir a leitura assídua e cuidadosa dos textos. Por isso, antes de ir para cada aula, é necessário revisitá-los com espírito de abertura a outras exegeses, incluindo aquelas que possam ser sugeridas por alunos; c -É necessário transmitir conhecimento seguro e validado. Mas no caso especial de Camões, é preciso ainda tentar que os alunos adquiram um gosto e entusiasmo pelas matérias.

Recuperando a memória destes princípios estabelecidos há mais de três décadas e mantidos ao longo de tantos anos, torna-se inevitável perguntar até que ponto eles se mantêm válidos². Pode o professor de hoje ignorar as alterações que foram tendo lugar em aspetos tão variados como a preparação e a motivação dos alunos, a sua capaci-

Matos e Isabel Almeida, a cadeira de Estudos Camonianos viria a ser criada em Coimbra no ano letivo de 1977-78, sob proposta de Aníbal de Castro. O mesmo Professor viria depois a regê-la até à sua aposentação, ocorrida em 2004. Para além de mim próprio, participou ainda na regência da cadeira, por vários anos, o Doutor José Carlos Seabra Pereira.

2 À distância de mais de três décadas, recordo que havia sobretudo da minha parte dois argumentos de militância. O primeiro resultava da tendência para ajustar a lecionação da cadeira aos programas que se encontravam em vigor no Ensino Básico e Secundário; o segundo relacionava-se com o que parecia ser a necessidade de modernizar a análise textual, seguindo as orientações e os métodos da narratologia e da semiótica. 
dade de ler nas aulas e para além delas? Deve o professor permanecer insensível perante a evidência de que o saber da sua cadeira deixou de ter a relevância social que tinha noutros tempos?

A estas importantes alterações há que acrescentar outras de não menor repercussão. Refiro-me à heterogeneidade dos públicos e à mudança que entretanto se operou na relação existente entre o professor e o aluno. Numa turma de 90 inscritos, o mais provável é que a grande maioria aceite e louve um discurso acessível e simplificador; isso não impede, contudo que surjam solicitações exigentes e imprevistas. É verdade que hoje não frequentam a cadeira muitos candidatos a professores de Português. Em contrapartida, frequentam as aulas cidadãos italianos que conhecem Petrarca e espanhóis que leram Garcilaso (algumas vezes, em níveis de profundidade maior do que os portugueses que estudaram Camões no Ensino Secundário). Há também alunos de história de arte que estudam a pintura ou a música do século XVI. Matriculam-se ainda alunos brasileiros para quem o século XVI pode ter um sentido diferente daquele que tem para um aluno europeu. Isto para não falar daqueles que frequentam a cadeira como opção livre e que tanto podem vir da área de jornalismo como do curso de Turismo. Nestes casos, a cadeira pode ser escolhida por motivos estritamente práticos: o horário de funcionamento, por exemplo, que pode inviabilizar a matrícula noutras cadeiras, porventura mais desejadas.

Por sua vez, a relação entre professor e aluno alterou-se em muitos aspetos. Não me refiro apenas à erosão da autoridade do professor, que vem assinalando o ambiente escolar e universitário ${ }^{3}$. Falo 
também da força vinculativa que antes tinha a "Bibliografia" dactilografada que era fornecida pelo professor no início das aulas e das iniciativas de pesquisa levadas a cabo pelos bons alunos, que eram sempre frequentadores de bibliotecas e até, algumas vezes, construtores de tertúlias pontuais.

O texto que agora decidi publicar constitui uma tentativa de resposta àquilo que é, ao mesmo tempo, uma dificuldade e um estímulo. Se antes era possível obrigar uma maioria de alunos a leituras introdutórias de 200 páginas (Cidade, Saraiva, Pimpão) hoje essa prática deixou de ser viável e corrente. Esses alunos não desapareceram por completo. Mas é mais realista pensar naqueles que resistem a leituras que ultrapassem quinze páginas. Nestas circunstâncias, o meu objetivo só pode ser o de conciliar as características de exigência e profundidade próprias do ensino universitário com as expectativas e as necessidades dos públicos estudantis com que venho convivendo ao longo dos últimos anos na Faculdade de Letras de Coimbra ${ }^{4}$.

Não se trata assim de publicar mais um “ensaio" sobre Os Lusiadas, pelo menos no sentido orgânico da palavra. Embora contenha uma visão personalizada do poema, assente naquilo que designo por of cina de Camões, o texto que agora vem a lume pretende sobretudo funcionar como um guião de estudo. O objetivo a alcançar é de natureza dupla: o de que ninguém deixe de ter um roteiro fundamentador das aulas; e o de que, ao mesmo tempo, nenhum aluno fique sem estímulo para seguir a sua curiosidade e para gerir a sua inquietude. 
O itinerário que agora proponho corresponde assim a uma tentativa de hospitalidade, no sentido de abrangência que se impõe 5 . A segmentação dos assuntos reproduz, em termos gerais, a parte da cadeira que é consagrada a Os Lusíadas (e apenas essa parte). Deixo assim de lado, por agora, outras questões que integram o programa e que poderiam complementar a presente proposta: para além da Lírica, penso em problemas de inserção periodológica, na receção estética, crítica e cívica da obra camoniana ou na excecional presença que a figura e a obra de Camões vêm mantendo no cânone literário escolar.

Refira-se ainda que o grau de aprofundamento de cada assunto depende também da reação dos alunos. Em regra, estes interessam-se pelos assuntos mais polémicos ou por aqueles que permanecem envoltos em "mistério"; sentem-se mais atraídos por um episódio do que por outro, como é natural. Estas respostas condicionam desde logo o trabalho de análise de textos, que constitui a prática central das aulas.

\section{O TEXTO DE OS LUSÍADAS E A VONTADE DE CAMÕES}

\subsection{A GUERRA DOS PELICANOS}

Uma vez que Os Lusíadas foram publicados ainda em vida do autor, poderia pensar-se que não existem problemas de autenticidade textual a tratar. A verdade, porém, é que esses problemas existem e estão ainda longe de se encontrar esclarecidos. Dos talvez cerca de 150 exemplares editados em 1572, sobra ainda hoje o número impressionante de cerca de 35 . A preservação de uma percentagem

5 Sobre o conceito de hospitalidade escolar e sobre a sua importância enquanto fator que contraria o desinteresse dos alunos, veja-se o já citado estudo de Eirick Prairat (em especial, pp. 207 e ss.). 
tão elevada de exemplares (em estado variável de conservação) certifica o cuidado que, ao longo dos séculos, o livro inspirou aos seus possuidores.

Os volumes em causa podem pertencer a duas edições diferentes ou a uma só edição. As posições sobre esta querela foram evoluindo ao longo dos séculos e ainda hoje têm que considerar-se inconclusivas. Os que defendem a existência de duas edições do poema no mesmo ano ou em anos diferentes assinalam como diferença mais visível a configuração do pelicano da portada: em alguns exemplares, supostamente pertencentes à edição "menos fiel”, este surge virado para a direita do leitor e noutros, que se cria pertencerem à edição "mais fiel”, o mesmo pelicano surge virado para o lado oposto. Outros porém, vêem nessa diferença um mero indício de que o processo de impressão da obra foi longo e atribulado, restando hoje exemplares que atestam diferentes estados daquela que, afinal, pode ser a mesma edição. A verdade é que os exemplares conservados ostentam variantes que vão da simples gralha a ultracorreções atribuíveis aos tipógrafos. Nessa medida, e apesar de continuarem em curso trabalhos que visam o aclaramento deste enigma, aguarda-se ainda uma edição verdadeiramente crítica daquele que foi e continua a ser o texto mais influente da cultura portuguesa ${ }^{6}$.

6 Sobre este complexo problema, vejam-se K. David Jackson (2003), Valeria Tocco (2005) e M. Helena da Rocha Pereira "A transmissão manuscrita de Os Lusíadas", in Camoniana Varia, pp.33-51.

A referência mais desenvolvida e atualizada sobre este tema de cariz quase policial é contudo o magistral estudo assinado por Vítor Aguiar e Silva, intitulado " A guerra dos pelicanos: o problema textológico da edição princeps de Os Lusíadas" "in A Lira Dourada e a tuba canora, pp.23-54. 


\subsection{AS ESTÂNCIAS DESPREZADAS OU OMITIDAS}

Uma outra questão relacionada com a textualidade da epopeia camoniana diz respeito às chamadas estâncias "esquecidas" “omitidas" ou "desprezadas". De facto, para além das que figuram na primeira edição e, por via dela, em quase todas as que se lhe seguiram, existe um conjunto relativamente numeroso de outras estâncias reportadas aos seis primeiros cantos e a vários passos da obra, que foram encontradas por Manuel de Faria e Sousa na livraria de Pedro Coelho, livreiro da Corte de Filipe $\mathrm{II}^{7}$, e por ele consideradas como autenticamente camonianas $^{8}$. Ainda que seja impossível considerá-las no mesmo plano daquelas que figuram no livro publicado em vida de Camões, justifica-se prestar-lhe alguma atenção. Seguindo os argumentos de Vasco Graça Moura, também elas me parecem a mim ter saído da pena do poeta; mesmo que assim não seja, trata-se, no limite, de textos concebidos sob a égide e a inspiração direta de Camões?: de tal forma que bem pode dizer-se que, se não foram escritas por ele,

7 O facto de as referidas estâncias se encontrarem na corte de Madrid deve ser tida como natural. Para lá também foi enviado, por exemplo, o espólio de João de Barros.

8 Cf. Lusiadas de Luis de Camoens comentadas por Manuel de Faria e Sousa, Madrid, 1639, tomo I, coluna 37 (edição comemorativa do IV Centenário da publicação d' Os Lusíadas, Lisboa, 1972).

9 Depois de analisar a questão da autenticidade, enumerando vários argumentos a seu favor, V. G. Moura conclui desta forma o seu raciocínio: "nem por isso deixarão elas de ter o maior interesse, quer pela análise dos critérios que fixaram a versão final d' Os Lusíadas quer pela apreciação da grande qualidade literária que muitas delas intrinsecamente têm" ("Oitavas esquecidas de Camões", in Os penhascos e a serpente, p.186). Por sua vez, Valeria Tocco (2005), contrariando a maioria daqueles que se interessaram por este assunto, considera como sendo de "origem camoniana", não apenas os que foram encontrados na livraria de Pedro Coelho mas também, pelo menos, algumas das que são referidas por Faria e Sousa (Vol. I, col. 39) como incluídas no chamado manuscrito de Montenegro. Neste sentido, a camonista italiana admite a possibilidade de as 3 versões manuscritas que se conhecem (a do Cancioneiro de Luís Franco Correia e as duas transcritas por Faria e Sousa) dizerem respeito a "três fases da elaboração poética, que acompanhavam o poeta ao longo da sua 
foram decerto concebidas por alguém que com ele manteve uma sintonia excepcional de tom e de talento.

Esta e outras questões, porém, fazem já parte de uma problemática que convém analisar globalmente. Refiro-me ao que designo por oficina de Camões e aos diversos focos de hesitação que, nessa mesma oficina, foram vividos pelo poeta, ao longo dos anos em que, em Portugal, na África ou na Ásia, trouxe o seu poema na inteligência, no entusiasmo e no afeto.

\section{A OFICINA DE CAMÕES}

Familiarizado com um processo de criação que tem o computador como centro, o leitor contemporâneo mal pode já imaginar o processo oficinal que estava por detrás da feitura de um livro no século XVI. Escrito à mão, em folhas de papel de textura bem mais grosseira do que aquele a que hoje estamos habituados, os caracteres eram desenhados com uma pena alimentada a tinta, que ia do sépia ao azul e ao preto. Escrevia-se então a um ritmo bem mais lento do que depois (no século XIX, o tempo do apogeu da escrita) se viria a escrever, o que favorecia a ponderação de cada palavra. De todo este processo resultava um manuscrito, por vezes muito volumoso, a requerer especiais cuidados de conservação, na medida em que podia ser irremediavelmente afetado pela humidade ou pelo fogo. Esse mesmo manuscrito era, em primeiro lugar, submetido ao exame de entidades civis e eclesiásticas, a fim de obter as licenças de impressão. A sua entrada na oficina do tipógrafo marcava uma nova fase da criação material da obra. De posse dele, o tipógrafo dedicava-se durante largo tempo (vários meses) ao trabalho de impressão: havia 
primeiro que selecionar os tipos metálicos, um a um, até compor uma palavra, uma frase, uma página. A unidade maior dependia do género em causa: poderia ser um capítulo, um ato ou um canto, por exemplo, consoante se tratasse de uma novela, uma peça de teatro ou uma epopeia. Após a impressão, havia finalmente que coser os fólios e proceder à encadernação dos diferentes exemplares.

Os volumes eram também compostos um a um, já que a matriz ia sendo desmanchada à medida que cada livro ia avançando no processo de impressão para vir depois a ser reconstituída. Este processo tanto dava azo a erros (não cometidos em exemplares anteriores) como a melhorias. Assim se explicam as diferenças maiores ou menores, que hoje se verificam entre diferentes exemplares de uma mesma edição quinhentista. Para além de todas as diferenças de ritmo, que bem podem deduzir-se do que fica sumariamente evocado, esta maneira de proceder obrigava o escritor a um tempo de ponderação mais intenso e mais alargado do que aquele que atualmente se verifica ${ }^{10}$.

Por todos estes motivos, o processo criativo de uma obra como Os Lusíadas teve que desenrolar-se ao longo de muitos anos. Porque o texto demorou muito tempo a escrever, desde logo; mas porque é certo que demorou também muito tempo a pensar. Não sendo possível determinar quando é que a ideia acudiu, pela primeira vez, à mente do poeta, é seguro que ela por lá andou em fase de sobressaltada germinação ao longo de vários anos, conhecendo, quase de

10 A este respeito, o aluno pode consultar com proveito o já antigo opúsculo de Tito de Noronha sobre a imprensa portuguesa do século XVI. Se se mostrar mais interessado no assunto, pode ser remetido para o recente manual de Alberto Corbeto e Marina Garone, Historia de la tipografía. La evolución de la letra desde Gutenberg hasta las fundiciones digitales, Lleida, Editorial Milenio, 2015 (em especial, o primeiro capítulo). 
certeza, formas diferentes daquela em que depois veio a fixar-se ${ }^{11}$. Muito provavelmente, entre a ideia original do poeta e aquele que viria a ser o resultado saído dos prelos de António Gonçalves ocorreram transformações importantes de forma e de substância. Como alvitra W. Storck, talvez Camões, ainda em Lisboa, tenha começado por querer escrever em verso apenas a viagem descobridora de Vasco da Gama, ocorrendo-lhe depois agregar a História de Portugal em registo de enquadramento e amplificação. Talvez o plano inicial não contemplasse, pelo menos com tanto destaque, alguns episódios que nos habituámos a considerar como partes obrigatórias do poema; outros podem até ter resultado de aditamentos de última hora, como se imagina que possa ter acontecido com as estâncias que correspondem ao discurso do Velho do Restelo (Chaves de Melo). Por outro lado, seria estranho que Camões se tivesse limitado a escrever apenas as estâncias que acabou por incluir no poema; o mais provável é que, antes da entrega do manuscrito (e após longo e difícil exame de consciência), o poeta tenha procedido a uma escolha auto-censória, ditada por motivos de ordem estética, moral ou ideológica ${ }^{12}$.

A impossibilidade de resolver estas incógnitas com absoluto rigor não deve impedir-nos de analisar alguns dos pressupostos e consequências que delas derivam. A verdade é que, na sua complexidade, Os Lusíadas refletem um processo criativo fortemente tensional. E a circunstância de terem chegado ao nosso conhecimento sob a forma

11 Para uma aproximação ao problema da cronologia de composição do poema, veja-se Houwens Post.

12 O alvará régio que concede licença de impressão foi lavrado no dia 24 de setembro de 1571, o que faz supor que a composição do poema tenha sido iniciada pouco depois, nos últimos meses do mesmo ano. Por sua vez, o alvará que concede a Camões a tença de 15000 reais está datado de 28 de julho de 1572, estabelecendo que o pagamento se faça a partir de 12 de março do mesmo ano (data provável da publicação do poema). 
de canto inspirado (ou seja, de totalidade perfeita) não deve impedir-nos de ter em conta os pólos de hesitação em que supostamente assentou a sua génese.

A tentativa de reconstituir esses polos reconduz-nos a uma oficina na qual Luís de Camões decerto longamente trabalhou. É certo que desconhecemos como se desenvolveu esse processo mental; o texto que chegou ao nosso conhecimento, porém, torna legítima e útil uma tentativa sumária de aproximação.

Passada esta fase de aproximação introdutória, passaremos a algumas dessas questões, assinalando, desde já, que, na sua maioria, ela apresentam uma tonalidade disjuntiva ou dialética.

\subsection{A SUBSTÂNCIA DA MATÉRIA: A HISTÓRIA E O MITO}

Um dos principais dilemas que Camões por certo enfrentou foi a natureza da substância a escolher para o seu poema: deveria optar por matéria lendária ou deveria fixar-se em matéria verídica? Não lhe faltavam modelos de um e de outro quadrante, embora talvez possa dizer-se que eram mais abundantes e prestigiados aqueles que assentavam no primeiro figurino.

A favor da matéria lendária ou fantasiosa estava a margem de liberdade criativa de que o poeta passava a dispor, muito superior àquela que conservaria se viesse a optar por matéria verídica ou histórica. A vantagem da história advinha da capacidade que, a partir dela, o poeta teria de influenciar o público recetor. É sabido que mais do que a ficção (mesmo tratando-se de fição verosimil) a verdade detém um potencial persuasivo que permite a quem fala ou a quem escreve tocar mais profundamente a quem ouve ou a quem lê.

Ora, como bem sabemos, Camões viria a optar pela matéria verídica, tomando-a como base dos dois níveis da sua narração: a História de Portugal, contada encadeadamente por Vasco da Gama ao rei de 
Melinde (III, 1- v, 89) e, de forma seletiva, por Paulo da Gama ao catual (vII, 1-42), e a viagem à Índia, contada pelo narrador de primeiro nível a um destinatário interno. Num caso e no outro a margem de efabulação do poeta reside praticamente na seleção dos episódios: podia não ter incluído o episódio de Inês ou não ter feito depender a Batalha do Salado da súplica da "fermosíssima” Maria; podia ter conferido menos importância ao facto de Nun’Álvares Pereira defrontar os irmãos em Aljubarrota. No que se refere ao essencial da matéria histórica, contudo, o poeta tomou por base os factos registados nas crónicas que decerto conheceu: as Crónicas breves de Santa Cruz para a parte respeitante ao período medieval e as Crónicas de Castanheda e de Barros, para a parte da expansão asiática ${ }^{13}$.

A quota de liberdade ficou reservada para a fábula mitológica. Foi usando dessa liberdade que colocou Vénus como protetora dos portugueses e Baco enquanto opositor da sua chegada à Índia. Do mesmo modo que resulta essencialmente da sua inventiva a construção da figura do Adamastor: enquanto oponente à viagem, desde logo, mas, sobretudo, enquanto vítima de um logro amoroso.

Desta associação entre verdade e fantasia não chega porém a resultar uma contradição. A mitologia existe no poema não para lhe servir de contraponto mas para sublinhar a verdade histórica. É com a verdade que se inicia o poema e é com ela que acaba, como que exaltando a importância central desta escolha camoniana.

Torna-se muito revelador que esta opção do poeta tenha sido sublinhada através de uma clara e insistente demarcação relativamente aos modelos fantasiosos, concretizados sobretudo nos poemas épicos italianos do Renascimento (em particular o Orlando innamorato - 1495 
e o Orlando furioso -1516), ambos fundados em peripécias inverosímeis (I,11-14); mesmo no final, quando poderia ter concluído o seu poema com a apoteose mitológica da ilha dos Amores, Camões prefere fazer regressar os heróis à Pátria $(x, 144)$. E é nessa base que se conclui a epopeia, com um apelo saído da história e dirigido à história: o apelo para que D. Sebastião retome a missão original do Reino que Afonso Henriques havia fundado sob o signo da cruzada e que o Rei contemporâneo deveria agora refundar, orientando a sua ação contra o xerifado de Marrocos.

\subsubsection{O GRAU DE PRESENÇA DO NARRADOR}

Uma outra hesitação muito provavelmente sentida por Camões é de caráter técnico-formal. Em relação à dificuldade antes assinalada, esta pode parecer destituída de grande significado. Em boa verdade, porém, não é assim. Trata-se, designadamente, de optar entre dois modelos de narrador, que podemos sumariamente designar por presente ou ausente. Optando pelo primeiro modelo, Camões poderia comentar, de perto, os episódios narrados (mesmo sendo eles de cunho histórico); se escolhesse o outro figurino, os acontecimentos evocados oferecer-se-iam ao leitor de forma mais pura ou imediata. Trata-se, afinal, grosso modo, da oposição que na Antiguidade Clássica se verifica entre o cânone homérico (onde a figura do narrador surge mais diluída) e o cânone virgiliano, caracterizado pela presença mais operante do narrador ${ }^{14}$.

No caso vertente, Camões optou pela matriz virgiliana. Depois de ter escolhido a matéria histórica em detrimento da lendária, interessava-lhe um narrador "ativo", que pudesse tirar partido dos episódios

14 Sobre as relações que a este respeito podem estabelecer-se entre Os Lusíadas e o cânone épico da Antiguidade Clássica, podem remeter-se os alunos para Maria Helena da Rocha Pereira e Américo Costa Ramalho. 
evocados junto dos destinatários diretos. Sem essa presença reguladora do sentido o poema ganharia em diversidade mas perderia em organicidade e coerência. É através da sensibilidade expressa pelo narrador que o leitor fica habilitado a articular o sentido de episódios tão diferentes como Inês de Castro, os Doze de Inglaterra ou a Ilha dos Amores (quadros que, de resto, mantêm, entre si, uma relação de contiguidade, bem sinalizada pelo narrador).

Os Lusiadas transformam-se assim num telling contínuo e a voz que conduz a narrativa não se limita a "mostrar" as diferentes peripécias, investindo também fortemente na interpretação moral e ideológica.

\subsection{O HERÓI (INDIVIDUAL OU COLETIVO?)}

Uma outra hesitação - ainda central - deve ter acometido a mente de Camões, levando-o talvez a traçar cenários alternativos. Se é certo que a elaboração de uma epopeia pressupõe a escolha de um herói (não há realmente epopeias exclusivamente centradas em figuras comuns), já a natureza desse herói envolve escolhas: pode o protagonista ser mais ou menos ativo, desde logo; pode depois ser mais ou menos humanizado (sentindo medo, por exemplo). Na epopeia de Camões, contudo, a escolha opera-se ainda em função de um outro critério: trataria o poema de um herói individual ou de um herói coletivo?

Qual a opção mais consentânea com as escolhas já mencionadas? Poderia Camões encontrar um herói individual que fosse verdadeiro e pudesse funcionar como exemplo, aos olhos dos leitores do poema?

Pode ser que o poeta tenha ponderado algumas possibilidades: o próprio Gama, desde logo, talvez Afonso Henriques ou Nun'Álvares Pereira. Em boa verdade, porém, a verdade histórica impedia-o de consumar uma eleição deste tipo. Em qualquer destas figuras se vislumbravam traços de heroísmo; mas em nenhuma delas se cumpria, na íntegra, um modelo que pudesse funcionar como pólo épico 
aglutinador e como referência para os destinatários que o autor pretendia tocar.

O que acabamos por ver n' Os Lusíadas é assim uma moldura de heroísmo, completa e exigente. Dela faz parte um conjunto de virtudes de natureza moral, intelectual e física. À medida que as diferentes figuras são confrontadas com a dita moldura, as insuficiências vão-se tornando evidentes: Afonso Henriques, apesar de toda a sua bravura, não é um filho virtuoso; da mesma forma, D. Afonso IV não sabe usar da misericórdia para com Inês; por sua vez, Vasco da Gama, o comandante das naus descobridoras, não revela nenhum tipo de familiaridade com as musas. Esta longa série de incompletudes levou já alguns críticos a concluir que Camões reserva para si próprio o estatuto de herói (Sena, 1972; Macedo, 1980). É sabido que o poeta tinha a poesia em altíssimo conceito, considerando-a como forma suprema de Arte e como atividade superadora do tempo. O mais razoável será no entanto pensar que a sua decisão foi de outro tipo: a de transpor para o plano do coletivo a componente de heroísmo que normalmente os criadores reservam para o plano individual.

Mas se a evidência desta escolha não sofre contestação, já os pressupostos e consequências que dela derivam justificam algum exame. Tendo escolhido matéria histórica e tendo optado por um modelo enunciativo que lhe permitia não apenas contar mas também interpretar a ação, o autor visava chegar o mais possível junto dos seus contemporâneos, esclarecendo-os quanto ao passado (é essa a vocação original do poema épico) e influenciar o seu futuro. Ora, a escolha de um herói coletivo serve retamente esse desígnio: "o peito ilustre lusitano” que Camões se propõe cantar representa não apenas os que fizeram a História de Portugal mas também aqueles que nela podem vir a inscrever-se como heróis parcelares ou incompletos. Só assim se entende que depois de concluída a acção principal, o poeta tenha ainda sentido a necessidade de rematar a epopeia de forma apa- 
rentemente insólita: falo das estâncias finais e do apelo a uma nova partida que nelas existe. Trata-se da partida do Rei para África, qual Afonso Henriques ressuscitado e transfigurado, a quem Camões se oferece enquanto cantor e enquanto soldado (x, 155). Se o herói não fosse coletivo, o poema não poderia simplesmente ter este remate futurante, ávido de História.

\subsection{MitOLOGIA (CRISTÃ OU PAGÃ?)}

Uma outra escolha que Camões teve que fazer relaciona-se com o quadro mitológico. Poderia Camões, na linha da veracidade que adoptou, optar pelo fundo cristão e ter enjeitado os deuses do Olimpo? Sem dúvida. Mas o seu poema não teria então o equilíbrio que efetivamente tem. Ao incorporar n' Os Lusíadas uma fábula mitológica, à maneira dos poemas da Antiguidade, o autor visa alcançar, pelo menos, dois desígnios: pretende, em primeiro lugar, conferir beleza ao seu poema e fazê-lo de forma criativa (o que não conseguiria alcançar, recorrendo apenas a figuras da fé cristã); pretende ainda contrabalançar os níveis de verosimilhança com que revestiu os outros planos da ação. Se em Vénus a filiação virgiliana é muito evidente, a figura de Baco pode considerar-se uma inovação camoniana. Não se trata apenas de decalcar a deusa Juno que surge na Eneida e a resistência malévola por ela encarnada. Podendo ser encarado como metáfora do despeito, Baco opõe-se à chegada dos portugueses ao Oriente, temendo que eles o destronem justamente nos domínios que conquistou. Ainda assim, pode dizer-se que a figura excede a função que desempenha e nela podem ser vistos pelo menos alguns sentidos equívocos, que continuam a desafiar os comentadores ${ }^{15}$. 
Por vezes, Camões serve-se da mitologia para expressar juízos profundos sobre o Amor, a Vida, a Guerra, a Morte e a Natureza. É o caso, em tudo singular, do Adamastor. O episódio é, muitas vezes, lido em registo meramente épico. Nesta linha, destaca-se o facto de um gigante ameaçador proferir um conjunto de profecias dissuasoras e de, ainda assim, o Gama prosseguir o seu caminho, vencendo os receios infundidos pelas palavras do gigante. Mas a parte decisiva do episódio corresponde à história dos amores fracassados que o gigante vivera antes. Apaixonara-se por uma ninfa e como não fosse correspondido, deixou-se tomar pela fúria, lançando a guerra no Oceano. Foi então que Tethys e sua mãe (Dóris) o atraíram a uma cilada e, prometendo-lhe a satisfação dos seus desejos, o transformaram num penedo, condenando-o à morte somática e a uma terrível penitência psíquica. A sanção foi ainda muito agravada pela circunstância de, mesmo aprisionado, ter continuado a ver a responsável pelas suas desventuras ("e por mais dobradas mágoas / me anda Tetis cercando destas águas”, v, 59).

Deste episódio compósito (englobando uma dimensão épica mas também uma lírica e ainda outra trágica) se retiram vários tipos de conclusão: a de que o Amor não se compagina com a violência nem com os impulsos e a de que o castigo pela infração amorosa se revela particularmente tormentoso.

Em face deste exemplum, os portugueses que vão a caminho da Índia e do Império do Amor, que Vénus (sua protetora) se dispõe a favorecer, situam-se no pólo oposto: são perseverantes e dispõem-se a sofrer. Nessa medida lhes está virtualmente destinado o prémio que o Adamastor não soube merecer; e até Tétis, a ninfa esquiva 
por quem o gigante se perdeu, há-de figurar na ilha namorada, para, juntamente com as outras filhas de Nereu, ser ferida pelas setas amorosas e aí docilmente acolher os lusitanos (Ix, 48).

\subsection{RECOMPENSA(S) DO HERÓI}

Recompensar o herói faz parte dos preceitos da epopeia. A hesitação que Camões coloca na mente de Vénus (Ix, 18-21), há-de ele próprio tê-la sentido pessoalmente como problema a resolver. Como premiar um herói tão singular? A ideia da ilha namorada ajusta-se à figura da divindade que protege os portugueses. Enquanto deusa do amor, faz sentido que ela queira recompensar os nautas, proporcionando-lhe uma experiência de consumação erótica. De facto, o episódio serve, antes de mais, para amplificar a caracterização da própria personagem. Afinal, a deusa nascida das águas não dispensa a proteção aos portugueses apenas pelas razões aduzidas no primeiro consílio: os fortes corações, as vitórias em Marrocos e a semelhança entre o Português e o Latim (I, 33). Confrontada com o desconcerto e a rebeldia dos homens que (“... estão / Amando cousas que nos foram dadas, / Não para ser amadas, mas usadas”, Ix, 24) a deusa cípria pretende que os seus protegidos sejam intérpretes de um plano grandioso: nada mais nada menos do que regenerar a raça humana. Desta forma, o que vai suceder na ilha dos Amores não tem um caráter estritamente gozoso; o plano da deusa é também fazer com que os nautas enobrecidos e as ninfas previamente feridas com as setas amorosas de Cupido venham a dar origem a uma “progénie forte e bela”. Só essa progénie emergente será capaz de reconverter o mundo que, tal como Cupido certifica na sua viagem, se encontra em estado de "Erros grandes" (Ix, 25).

O amor que vai consumar-se naquela ilha é portanto fecundo, como fértil é a Natureza que a reveste, pejada de frutos e água cristalina, tanto corrente como represada. 
A consumação amorosa, tantas vezes interpretada em registo meramente fruitivo, constitui o prelúdio de uma nova Idade do Ouro, centrada no Amor e no Conhecimento. Assim se explica que logo após o ato amoroso, nautas e ninfas celebrem esponsais (Ix, 84) e participem num Banquete (x, 2-5) que pressupõe um nivelamento de condição (após o encontro erótico com as ninfas, os nautas estão enfim divinizados). Os marinheiros de D. Manuel são ainda premiados com a revelação do Tempo: a dádiva ocorre já nos "paços radiantes", através do relato de uma ninfa, que desvenda os feitos futuros dos Portugueses no Oriente, antes ouvidos a Proteu que, por sua vez, em sonhos, os tinha visto representados numa esfera transparente e oca (x, 6-73).

Por fim, Tétis, a titânide que desposa Vasco da Gama, vai conduzi-lo ao cimo de um alto monte, para lhe proporcionar a ele e aos seus companheiros os segredos do Espaço:

Faz-te mercê barão, a Sapiência

Suprema de, c'os olhos corporais,

Veres o que não pode a vã ciência

Dos errados e míseros mortais.

Sigue-me firme e forte, com prudência,

Por este monte espesso, tu c'os mais.

Assi lhe diz e o guia por um mato

Árduo, difícil, duro a humano trato.

A contemplação da máquina do mundo constitui, de facto, o Prémio supremo do herói camoniano, só limitado pela inacessibilidade do Criador: 
Quem cerca em derredor este rotundo

Globo e sua superfície tão limada,

É Deus: mas o que é Deus, ninguém o entende,

Que a tanto o engenho humano não se estende.

\subsection{A GUERRA E O AMOR}

Já depois de superadas as adversidades do cabo tormentório, encontrando-se a armada já na costa oriental de África, o narrador evoca um dos poucos momentos de distensão ao longo da viagem. É de noite e alguns marinheiros encontram-se em atitude de vigilância. Para permanecerem despertos, resolvem contar histórias. Instaura-se então uma querela entre dois soldados: Leonardo prefere contos de amores; mas Veloso pretende que se narrem histórias belicosas, alegando que se ajustam mais às "duras" circunstâncias em que se encontram". O episódio narrado por Fernão Veloso (vi, 43-69) é o dos Doze de Inglaterra e, apesar de se tratar de matéria típica de cavalaria, existe alguma dificuldade em ver nele as características antes proclamadas pelo narrador.

De facto, o ethos cavaleiresco que sobressai na história está longe de se esgotar na "guerra férvida e robusta" que o próprio Veloso havia anunciado cumprindo os requisitos de afeto defendidos por

16 Por entre as chamadas estâncias omitidas de Os Lusíadas encontradas por Faria e Sousa na livraria de Pedro Coelho contam-se três, interpoladas entre a 43 e a 44, que prolongam o debate entre Veloso e Leonardo. Confluindo no esbatimento da oposição entre a Guerra e o Amor e contribuindo para uma melhor compreensão dessas duas personagens que hão-de surgir no Canto Ix em posição antagónica: um imediatamente beneficiado pelo Amor (Veloso) e outro (Leonardo) mesmo aí perseguido pela má sina, que o obriga a correr atrás de Efire, a única ninfa que ainda não havia sido totalmente submetida pelas setas de Cupido e pela Fama que precedera a chegada dos nautas. 
Leonardo, com destaque para a generosidade do Magriço, posto à prova antes e depois do combate de Londres ${ }^{17}$.

Esta solução de compromisso aplica-se à generalidade do poema. É certo que na Invocação inicial, o poeta havia solicitado às Tágides uma inspiração bem clara, a proporcionar pela "tuba canora e belicosa / Que o peito acende e a cor ao gesto muda" (I, 4). Ao longo do poema, contudo, a oposição não é tão diametral como poderia supor-se. Para além das convenções do género - que realmente obrigariam o poeta a abdicar do estilo lírico - situa-se a idiossincrasia do poeta, que, de facto, não consente a separação entre a Guerra e o Amor ${ }^{18}$.

Por isso, vamos encontrar na epopeia camoniana uma constante associação entre episódios afetivos e bélicos: a participação de Afonso IV na batalha do Salado é uma consequência da súplica da formosíssima Maria, por exemplo; como Inês de Castro constitui uma denegação e um recuo dessa mesma conquista afetiva (já que são os cavaleiros e as espadas do Salado quem se encarniça contra o peito da donzela); mesmo em Aljubarrota, mais do que castelhanos e portugueses, Camões coloca frente a frente os amantes da Pátria e aqueles que a traíram.

Nessa perspetiva, tal como o narrador Fernão Veloso, Camões não conseguiu resolver o dilema, optando por uma conciliação que faz d' Os Lusíadas uma epopeia especial, na medida em que legitima a Guerra em função do Amor. É, de resto, com base num dos planos mais elevados do Amor (o Amor da Pátria) que todo o poema se institui e justifica, desde o primeiro ao último verso.

17 Por estes motivos, é possível concluir que o episódio se destina também a repor a ordem ofendida com a morte de Inês de Castro.

18 Sobre a permanência do temperamento lírico de Camões ao longo d’Os Lusíadas, recomenda-se sobretudo a obra de Roger Bismut que figura na Bibliografia final. 


\subsection{O(S) FINAL/AIS DO POEMA}

Um dos dilemas mais difíceis que Camões teve que resolver na intimidade da sua oficina mental foi, sem dúvida, a maneira como poderia finalizar o seu poema. À partida, haveria quatro formas de concluir e pode supor-se que o poeta ensaiou cada uma delas. A primeira seria constituída pelo simples regresso à "pária cara", antevisto nas ests. 16 e 17 do Canto Ix, em clima de enorme contentamento e consumado depois na est. 144 do Canto $\mathrm{x}$ :
Assi foram cortando o mar sereno,
Com vento sempre manso e nunca irado,
Até que houveram vista do terreno
Em que naceram, sempre desejado,
Entraram pela foz do Tejo ameno,
E a sua Pátria e Rei temido e amado
O prémio e glória dão por que mandou
E com títulos novos se ilustrou.

Embora cumprindo as exigências da verosimilhança, este final suspendia (ou mesmo rasurava) a intriga mitológica que constituíra o suporte da ação. É assim que, logo a seguir às duas primeiras estâncias do Canto Ix, o episódio da Ilha namorada é introduzido através de uma adversativa, abrindo a expetativa de uma apoteose. Tratava-se, sem dúvida, de uma solução congruente e que tinha a vantagem de congregar os dois planos que no poema se desenvolvem em paralelo: a mitologia e a história. Havia, no entanto, um óbice importante a esse tipo de consumação: tendo feito uma escolha central pela história em detrimento da lenda, corria-se o risco de, com este remate, se atenuar o impacto daquela escolha. Com efeito, depois de ter conferido a primazia à Verdade não poderia o poeta diluí-la ou rasurá-la, convertendo os seus intérpretes em puros deuses. 
Assim se explica que logo depois de se ter dedicado a uma longa e pormenorizada descrição dessa apoteose, o narrador tenha sentido a necessidade de desfazer qualquer tipo de equívoco, situando a ilha no plano estrito da Arte:

Que as ninfas do Oceano, tão fermosas

Thetys e a ilha angélica pintada,

Outra cousa não é que as deleitosas

Honras que a vida fazem sublimada.

Aquelas preminências gloriosas,

Os triunfos, a fronte coroada

De palma e louro, a glória e maravilha.

Estes são os deleites desta ilha.

$$
(\mathrm{IX}, 89)
$$

Uma terceira hipótese de conclusão (que emerge na sequência desta mesma desmitificação) é entrevista na célebre estância 145 do Canto $\mathrm{x}$, onde o poeta se revela profundamente descrente em relação à gente "surda e endurecida" que acaba de enaltecer:

Nõ mais, Musa, nõ mais, que a Lira tenho

Destemperada e a voz enrouquecida,

E não do canto, mas de ver que venho

Cantar a gente surda e endurecida.

$\mathrm{O}$ favor com que mais se acende o engenho

Não no dá a pátria, não, que está metida

No gosto da cobiça e na rudeza

D'ua austera, apagada e vil tristeza.

Seria, porventura, o remate que mais se adequaria ao ânimo do poeta; a verdade, contudo, é que esse desfecho equivaleria a uma negação retrospetiva de todo o poema; mas mais do que isso, cance- 
laria qualquer possibilidade de futuro. Encerrando o seu poema desta forma, o poeta como que rasgaria a sua obra, renunciando a qualquer esperança.

Finalmente, havia uma quarta possibilidade, aquela que seria porventura a menos esperada: a conclusão do poema poderia ser uma exortação superadora. Assim veio a acontecer, de facto. Superada a apoteose da ilha (logo denunciada como tratando-se de uma realidade "pintada"), afastada também a ideia de um desengano rasurante, restava a Camões o apelo ao Rei. No fundo, é isso que Os Lusíadas pretendem ser do princípio ao fim: um apelo a D. Sebastião. Neste caso, a exortação vai no sentido de que o monarca reconduza os portugueses ao ideal da cruzada. Marrocos, para onde parece apontar o dedo de Camões no final d 'Os Lusíadas, é visto como espaço de reconquista e, nessa medida, a partida dos portugueses para as partes d 'Além significa o retomar do destino providencial assinalado por Cristo em Ourique. Na medida em que afronta os interesses mouros instalados nas costas do Malabar, a viagem do Gama a Calecute pode ainda participar desse mesmo espírito; mas não há dúvida de que os perigos da perversão (da chatinagem e da mercancia) são aí bem mais ameaçadores. De resto, a própria história não daria grande margem a Camões para converter a viagem de Vasco da Gama e as suas negociações com as autoridades de Calecute em algo mais do que uma diligência comercial. O próprio Camões, soldado da Índia, tinha experimentado alguns dos desmandos éticos a que havia conduzido essa mesma viagem (que são, de resto, aflorados na profecia da ninfa, a partir da visão de Proteu ${ }^{19}$ ). Depois de ter narrado uma

19 A visão que da Índia tinha Camões encontra-se de alguma forma plasmada na carta que de lá escreveu (admitindo que estamos perante um texto autêntico). Nela diz o autor, designadamente, referindo-se a Goa, que é “ ...mãe de vilões ruins e madrasta de homens 
partida que nem sempre conduziu a bons resultados, Camões parece apontar o caminho da partida ideal. Poderia dizer-se que, no final do canto IV, já o Velho a tinha sinalizado como destino possível; mas as duas posições não coincidem inteiramente: enquanto aquela voz manifesta preferência pelo ideário humanista da renúncia irénica, no remate da sua epopeia, o poeta exorta o Rei a partir em atitude de conquista positiva; ou seja, enquanto África surge na boca do Velho como um mal menor (em si mesmo, o mal tinha sido desencadeado pelo primeiro que no mar havia posto seco lenho), para Camões, os montes de Ampelusa surgem como espaço e tempo de resgate.

\section{OS EFEITOS DAS ESCOLHAS DE CAMÕES}

Não restam dúvidas de que, ao longo de todo o processo criativo, Camões empreendeu escolhas coerentes. Para além de todo um talento arquitetural que os comentadores têm sublinhado ${ }^{20}$, é bem possível que a razão dessa coerência esteja também relacionada com um tópico ao qual nem sempre se tem atribuído a devida importância: refiro-me ao facto de todo o poema assentar numa interlocução entre o poeta e D. Sebastião. Iniciado convencionalmente com a Proposição (que corresponde às duas primeiras estâncias) e a Invocação (equivalendo esta às três estâncias seguintes), o poema prossegue com uma Dedicatória anormalmente extensa (treze estâncias). Nela se supera o habitual louvor do dedicatário (que, neste caso, nem sequer desempenha função de mecenas efetivo) para se transformar, na prática, o rei-ouvinte em interveniente ativo. De tal forma que, doravante,

honrados" (Obras Completas de Luís de Camões, edição de Hernâni Cidade, Lisboa, Círculo de Leitores, 1987, p.286).

20 De entre os camonistas que mais destacaram esta vertente chame-se a atenção para Jorge de Sena ( $A$ estrutura de Os Lusíadas) e António José Saraiva ("A Fábrica de Os Lusíadas"). 
tudo o que vai ser contado requer um entendimento duplo: o dos destinatários coevos mas também e principalmente o entendimento do Rei. Todos os episódios e todas as figuras ganham em ser relidos a esta luz. Em boa verdade, é a D. Sebastião que Camões conta histórias como a de Inês de Castro e a do Adamastor; é ainda tendo presente a figura do jovem Rei que Camões resolve premiar os nautas, no final, com a ilha do Amor e do Conhecimento.

Foi designadamente por isto que Camões optou por matéria histórica e que escolheu um modelo de narração onde a sua voz se pudesse fazer ouvir. Sem a consumação destas opções, o poema não poderia, de facto, funcionar como proclamação de esperança e apelo a um Rei vivo e jovem.

Ao efetuar as suas escolhas, o poeta como que desencadeou efeitos de sentido que se revelam importantes na configuração e nos sentidos da obra.

De entre os vários efeitos assim obtidos, destaquemos alguns dos que mais se repercutem nos sentidos globais do poema.

\subsection{A HiSTÓRIA DE PORTUGAL E A VIAGEM DO GAMA}

O primeiro efeito que cumpre destacar relaciona-se com a ligação existente entre a viagem do Gama e a História de Portugal, tal como é narrada ao Rei de Melinde pelo próprio Gama.

Chegado a Melinde, após ter escapado à cilada de Mombaça, Vasco da Gama é amistosamente recebido. E é sob interpelação do chefe melindano que vai situar-se no espaço e no tempo. Até aí, a narração tinha exclusivamente incidido sobre a viagem marítima, envolvendo as respetivas peripécias, interpoladas com a intriga mitológica. Chegou a vez de ser apresentado o último nível da ação. Sabendo nós que a escolha do poeta se verificou a favor de matéria factual, a narração não pode fugir a ela. O protagonista da viagem 
ao Oriente é também o narrador da História de Portugal; afigura-se ainda revelador que a ação que agora vai iniciar-se seja rigorosamente trazida até ao momento em que o narrador se encontra, ou seja, remonte à fundação do Reino para apenas se suster no momento em que as naus do Gama chegam a Melinde (II, 73). A conclusão a extrair só pode ser uma: a viagem do Gama constitui a continuação lógica de toda a História narrada por ele próprio. Não se trata de um parênteses nem de um facto menor. Antes pelo contrário: trata-se de um acontecimento culminante, que deve entender-se na sequência de Ourique, de Aljubarrota ou do Salado mas também de Inês de Castro ou do Adamastor. A viagem é relacionável com tudo isso e, em boa verdade, encontra-se impregnada de um telos, repartido entre um termo inicial (Ourique) e um termo final que se traduz no apelo a uma partida nova.

\subsection{SEBASTIÃO E O HERÓi COLETIVO}

Uma outra consequência das escolhas feitas por Camões - já o anotámos - é que Os Lusíadas não dispensam um herói coletivo. À luz da verosimilhança histórica, seria difícil de admitir um qualquer herói individual saído da História. Mas assentando o poema num desígnio persuasivo tão forte, o heroísmo teria de desempenhar um papel reforçado. Nessa medida, importava provar a D. Sebastião não só que o passado de Portugal se encontrava balizado pela Providência, mas também que existia um potencial de heroísmo pronto a eclodir se para tanto se viessem a concretizar determinadas condições de chefia.

Essas condições, que antes se tinham verificado com Afonso Henriques e com D. João I e Nun’ Álvares, pareciam agora de novo verificar-se na pessoa de D. Sebastião, visto por Camões como "maravilha fatal da nossa idade" (I, 6) ou seja, como ungido, desti- 
nado a reerguer a nação da "austera, apagada e vil tristeza" em que estava mergulhada.

\subsection{O DESGOSTO DO PRESENTE E O TÓPICO DA REFUNDAÇÃO}

Um outro efeito das escolhas camonianas revela-se particularmente impressivo. Refiro-me à quase inexistência do presente. De alguma forma, a condensação heróica do passado e o investimento esperançoso no futuro próximo conduzem a esse tipo de rasura. Mesmo centrando-se na História, Camões opta por não se referir à situação do Reino, no pressuposto de que ele constitui um entreato que não se ajusta nem ao passado nem ao futuro.

Abrangendo, ao mesmo tempo, uma seleção retrospetiva e projetando um futuro de redenção, Os Lusíadas envolvem um claro efeito fundante, tanto em termos estéticos como em termos cívicos.

Constituindo, do ponto de vista estético, uma epopeia de imitação, o poema de Camões converteu-se em algo de inimitável. É talvez porque na epopeia se canta um herói aberto que nela se admitem os fracassos e os recuos de um herói que se vence a si próprio, que os portugueses se puderam rever nela ao longo de tanto tempo. É porque Camões fala de si próprio ao longo do poema que ainda hoje nos podemos comover; é sobretudo porque a epopeia termina com um apelo que ainda hoje medimos as nossas forças em função de todos os desafios: já não diretamente para romper nos campos de Ampelusa mas ainda e sempre para encontrar um qualquer caminho de dignidade, de perseverança e de sentido identitário.

Neste século XXI, e para além de todas as diferenças, esses valores podem ser vistos como sinónimos aceitáveis da Glória e do heroísmo humanistas cantados por Luís de Camões há quase quinhentos anos. 


\section{BIBLIOGRAFIA (SELECIONADA) ${ }^{21}$}

ATIVA

CAmões, Luís de (1992). Os Lusíadas. Leitura prefácio e notas de Álvaro Júlio da Costa Pimpão/apresentação de Aníbal Pinto de Castro. $3^{a}$ ed., Lisboa: Instituto Camões.

VIDA, Marco Girolamo (1990). Arte Poética. Introdução, tradução e notas de Arnaldo M. Espírito Santo. Lisboa: Instituto Nacional de Investigação Científica/Centro de Estudos Clássicos da Universidade de Lisboa.

\section{PASSIVA}

A - Referências de Enquadramento

1. Bates, Catherine (ed.) (2010). The Cambridge Companion the Epic. Cambridge: Cambridge University Press.

2. Bernardes, José Augusto Cardoso (1999). História da Literatura Portuguesa (dir. de Carlos Reis), vol. II: Humanismo e Renascimento, (capítulo V). Lisboa/São Paulo: Editorial Verbo.

3. Corbeto, Alberto e Marina Garone (2015). Historia de la Tipografía. La evolución de la letra desde Gutenberg hasta las fundiciones digitales. Lleida: Milenio.

4. Noronha, Tito de (1874). A imprensa portuguesa durante o século XVI. Porto: Imprensa Portuguesa.

21 A Bibliografia camoniana destaca-se por ser particularmente abundante. Torna-se, por isso, inútil (senão contraproducente) fornecer aos alunos de hoje uma listagem demasiado extensa. Uma das obrigações do professor é hoje a de proceder a uma seleção equilibrada que possa servir aos diferentes tipos de alunos: aqueles para quem Camões constitui um autor de passagem fugaz contentar-se-ão com estes ou outros apontamentos e com um ou outro título de carácter geral e introdutório. Mas pode haver quem não se conforme com essa informação elementar. Mais uma vez a presente seleção visa satisfazer as necessidades de uns e de outros. 
5. Serrão, Joel e A. H. Oliveira Marques (dir.) (1998). Nova História de Portugal: do Renascimento à crise dinástica (coord. João José Alves Dias), vol. V. Lisboa: Editorial Presença.

B - Referências sobre a Globalidade da Obra Camoniana

1. Almeida, Aníbal (1996). O rosto de Camões. Lisboa: Imprensa Nacional/Casa da Moeda.

2. Berardinelli, Cleonice (2000). Estudos camonianos. Rio de Janeiro: Nova Fronteira [2a edição, revista e aumentada].

3. Castro, Aníbal Pinto de (2006). Páginas de um honesto estudo camoniano. Coimbra: Centro Interuniversitário de Estudos Camoniano.

4. Le gentil, Georges (1969). Camões. Tradução de José da Silva Terra. Lisboa: Portugália.

5. MACEDO, Helder (2007). "Introducción a Camões", in Elena Losada Soller (coord.), Camões. Los Lusiadas, Poesias, Prosas. Madrid/ Córdoba: Espasa Calpe/Almuzara [col. Biblioteca de Literatura Universal]. Ix-Lxxiv.

6. Matos, Maria Vitalina Leal de (1980), Introdução à poesia de Luís de Camões. Lisboa: Biblioteca Breve.

7. Moura, Vasco Graça (1987). Os penhascos e a serpente e outros ensaios camonianos. Lisboa: Quetzal Editores.

8. Pereira, Maria Helena da Rocha (2008). Camoniana varia. Coimbra: Centro Interuniversitário de Estudos Camonianos.

9. Ramalho, Américo da Costa (1992), Camões no seu tempo e no nosso. Coimbra: Almedina.

10. Saraiva, António José (1972). Luís de Camões. S/1: Europa/América.

11. SтоRск, Wilhelm (1897). Vida e Obra de Luís de Camões. Tradução e notas de Carolina Michaëllis de Vasconcelos. Lisboa: Academia Real das Sciencias. 
C - Bibliografia sobre Os Lusíadas

1. Alves, Hélio J. S. (2001). Camões, Corte-Real e o sistema da epopeia quinhentista. Coimbra: Centro interuniversitário de Estudos Camonianos/ Biblioteca Geral da Universidade de Coimbra.

2. _ (2010). "Teoría de la épica en el Renaciminento portugués", in María José Vega Ramos e Lara Vilà (eds.), La teoría de la épica en el siglo XVI: España, Francia, Italia y Portugal. Vigo: Editorial Academía del Hispanismo. 137-173.

3. Bernardes, José Augusto Cardoso (2000). "As estâncias finais de $O s$ Lusíadas ou o nunca ouvido canto de Camões”. Máthesis [Universidade Católica Portuguesa]. 9: 69-84.

4. Bismut, Roger (1974). Les Lusiades, confession d'un poète. Paris: Centre Culturel Portugais.

5. Cidade, Hernâni (1975). Luís de Camões: o Épico, vol. II. Amadora: Bertrand [ $4^{\text {a }}$ edição, corrigida e aumentada].

6. Jackson, David Kenneth (2003). Luís de Camões e a primeira edição de Os Lusiadas de 1572. CD-ROM produced by Portuguese Literary and Cultural Studies, Center for Portuguese Studies, University of Massacuhttes Dartmouth.

7. Figueiredo, João R. (2007). "Pais tiranos: O Baco de Os Lusíadas e Camões” in António M. Feijó e Miguel Tamen (org.), A teoria do programa. Uma homenagem a Maria de Lourdes Ferraz e a M.S. Lourenço. Lisboa: Universidade de Lisboa. 19-37.

8. HuE, Sheila Moura (2202). "Em busca do cânone perdido. Manuscritos e impressos quinhentistas das variantes textuais e das atribuições autorais”. Revista Camoniana. 3. ${ }^{\text {a }}$ série. 12: 171-193.

9. MACEDO, Hélder (1980). Camões e a viagem iniciática. Lisboa: Moraes Editores.

10. MAcedo, Jorge Borges de (1979). Os Lusíadas e a História. Lisboa: Editorial Verbo. 
11. Matos, Maria Vitalina Leal de (2003). Tópicos para a leitura de Os Lusíadas. Lisboa: Editorial Verbo.

12. Mazzochi, Giuseeppe (2001). "Introduzione”, in Luís Vaz de Camões, I Lusiadi. Traduzione di Ricardo Averini, note di Valeria Tocco. Milano: Biblioteca Universale Rizzoli. 7-82.

13. MeLo, Gladstone Chaves de (1985). "Uma interpretação do episódio do Velho do Restelo". Revista da Universidade de Coimbra. XxхıI: 341-345.

14. Nóbrega, Luiza (2008). O canto molhado. Metamorfose d' Os Lusiadas. Leitura do poema como poema. Lisboa: Aqva.

15. Post, Houwens (1972). A Cronologia da composição de várias passagens de Os Lusíadas. Separata da Revista Ocidente. Revista Portuguesa de Cultura. [n. $\left.{ }^{\circ} 415\right]$ Vol. LxxxiII.

16. Saraiva, António José (1992). "A Fábrica de Os Lusíadas" in António José Saraiva, Estudos sobre a arte d'Os Lusíadas. Lisboa: Gradiva. 47-75.

17. SENA, Jorge de (1980). A estrutura de Os Lusíadas e outros estudos camonianos e de poesia peninsular do século XVI. 2. ${ }^{\mathrm{a}}$ ed., Lisboa: Edições 70.

18. SÉrgio, António (1925). Camões e D. Sebastião. Rudimentar organização de documentos para o estudo de um problema curioso. Paris-Lisboa: Livrarias Aillaud e Bertrand.

19. Silva, Luís Oliveira e (1999). Ideologia, Retórica e ironia n’ Os Lusíadas. Lisboa: Salamandra.

20. Silva, Vítor Aguiar e (2008). A Lira Dourada e a Tuba Canora. Lisboa: Cotovia.

21. Tocco, Valeria (2005). A lira destemperada. Estudos sobre a tradição manuscrita de Os Lusíadas. Bari: Adriatica Editrice.

22. Walker, Roger M. (1972). "Reacção ou Progresso? Baco ou Vénus? Pergunta de Camões ainda sem resposta”. Ocidente. Revista Portuguesa de Cultura. Número especial: 173-181. 
(Página deixada propositadamente em branco) 